\title{
SIFAT FISIK-KIMIA DAN ORGANOLEPTIK BAWANG GORENG PALU PADA BERBAGAI FREKUENSI PEMAKAIAN MINYAK GORENG
}

\author{
Physical-Chemical and Organoleptic Properties of Palu Fried Onions at the Varying Utilization Frequency \\ of Cooking Oil
}

\author{
Nur Alam, Rostiati, Muhardi \\ Program Studi Agroteknologi, Fakultas Pertanian, Universitas Tadulako, Jl. Soekarno-Hatta Km. 9, \\ Tondo, Palu, Sulawesi Tengah 94118 \\ Email: alam_thp60@yahoo.coi.id
}

\begin{abstract}
ABSTRAK
Telah dilakukan penelitian untuk mengetahui sifat fisik-kimia dan organanoleptik bawang goreng Palu yang digoreng pada berbagai taraf frekuensi pemakaian minyak goreng yaitu $\mathrm{F}_{0}$ : minyak segar, $\mathrm{F}_{1}: 1$ kali pemakaian, $\mathrm{F}_{2}: 2$ kali pemakaian, $\mathrm{F}_{3}: 3$ kali pemakaian, $\mathrm{F}_{4}: 4$ kali pemakaian, $\mathrm{F}_{5}: 5$ kali pemakaian dan $\mathrm{F}_{6}: 6$ kali pemakaian, setiap taraf diulang tiga kali. Frekuensi pemakaian minyak goreng pengaruhnya sangat nyata menurunkan warna, tekstur, kadar air, minyak dan tingkat kesukaan panelis terhadap kerenyahan bawang goreng Palu serta meningkatkan laju oksidasi asam lemak tidak jenuh pada minyak goreng. Mutu fisik-kimia dan organoleptik bawang goreng Palu secara berturut-turut terbaik diperoleh dari penggorengan menggunakan minyak goreng segar, 1, 2 dan 3 kali pemakaian. Pemakaian minyak goreng $>3 \mathrm{kali}$, asam lemak bebas telah teroksidasi sehingga kurang layak untuk digunakan jika ditinjau dari aspek daya tahan simpan bawang goreng dan kesehatan.
\end{abstract}

Kata kunci: Bawang goreng, sifat fisik-kimia dan organoleptik, frekuensi pemakaian minyak goreng

\begin{abstract}
The objectives of the study were to determine the physical-chemical and organoleptic properties of Palu fried onions at the varying utilization frequency of cooking oil, i.e. F0 : fresh oil , F1 : 1 time of using, F2 : 2 times of using, F3 : 3 times of using, F4 4 times of using, F5 $: 5$ times of using and F6 6 times of using, the each level was replicated three times. The frequency of cooking oil utilization was significantly affected to decreasing color, texture, moisture content, oil content and panelist preference level on the crispness of Palu fried onions as well as increasing oxidation rate of unsaturated fatty acids at the cooking oil. Physical - chemical and organoleptic quality of Palu fried onions were obtained of the best fresh frying utilization cooking oil, 1,2, and 3 times of using cooking oil , respectively. The use of cooking oil more than 3 times oxidized free fatty acids, so it is less feasible to use based on the life time and health aspects of fried onions.
\end{abstract}

Keywords: Fried onion, physical-chemical and organoleptic properties, frequency of utilization cooking oil.

\section{PENDAHULUAN}

Salah satu produk unggulan bawang merah lokal Palu adalah bawang goreng siap saji yang lazim disebut "Bawang Goreng Palu". Tercatat 36 industri yang tersebar di Kota Palu dan sekitarnya mengolah bawang merah lokal Palu menjadi bawang goreng. Bawang goreng Palu memiliki tekstur padat, rasanya gurih serta aromanya khas sehingga banyak disenangi oleh masyarakat. Bawang goreng Palu Laris sebagai oleh-oleh ke sejumlah daerah di Indonesia dan negara seperti Prancis, Malaysia, dan China (Media Indonesia, Senin 15 September 2008) sehingga dikategorikan sebagai komoditi khas Sulawesi Tengah berdaya saing tinggi.

Kendala pengembangan bawang goreng Palu dipengaruhi oleh mutu terutama daya tahan bawang gorengnya masih sangat terbatas. Produk makanan yang pengolahannya menggunakan minyak goreng, termasuk bawang goreng sangat rentan terhadap reaksi hidrolisis dan oksidasi sehingga 
mudah mengalami kerusakan. Ete dkk. (2009) melaporkan karakteristik bawang goreng Palu telah mengalami penurunan drastis setelah penyimpanan 2 bulan. Minyak yang terserap pada produk ini termasuk kategori sangat tinggi yakni $>30 \%$ (Ete dan Alam, 2009) sehingga dapat memacu reaksi hidrolisis dan oksidasi. Di samping itu, kadar minyak yang berlebihan dapat mengurangi penampakan produk, merugikan produsen karena meningkatkan biaya produksi sedang bagi konsumen kurang disukai dengan alasan kesehatan. Konsumsi minyak berlebihan dianggap sebagai kunci penyumbang kolesterol, darah tinggi dan penyakit jantung koroner (Albert dan Mittal, 2002).

Mutu makanan gorengan (sifat kimia, fisik dan sensoris) sangat ditentukan oleh kualitas bahan baku (kadar air, protein, pati, ukuran bahan, komposisi bahan pelapis atau adonan dan bahan aditif) serta variabel pengolahan seperti waktu dan suhu penggorengan, frekuensi pemakaian minyak, kontrol kelembaban, dan reduksi kandungan minyak (Shieh dkk., 2004; Basuny dkk., 2009 dan Adams, 2004).

Industri bawang goreng di Kota Palu dan sekitarnya pada umumnya menggunakan minyak goreng $>3$ kali untuk menggoreng bawang goreng (Alam dkk., 2013). Menurut Nazrun dkk. (2007) biasanya, minyak goreng yang digunakan berulang kali menggoreng makanan untuk menghemat biaya hingga minyak berubah warna, bau, rasa atau konsistensi. Frekuensi pemakaian minyak goreng termasuk salah satu variabel pengolahan yang dapat mempengaruhi mutu makanan gorengan. Menurut Hojjatoleslamy dan Sedaghat (2012) pemakaian minyak goreng berulang-ulang dapat menyebabkan penurunan lightness dan tekstur potato chips serta meningkatkan indeks konsistensi minyak goreng dan bilangan peroksida. Onigbogi dkk. (2011) menjelaskan bahwa frekuensi pemakaian dan jenis minyak goreng yang berbeda memberikan pengaruh sangat nyata terhadap sifat sensoris keripik ubi jalar. Selain itu, perubahan komposisi asam lemak sangat nyata dipengaruhi oleh frekuensi pemakaian minyak goreng (Andrikopoulos dkk., 2002; Alireza dkk., 2010; Chacko dan Rajamohan, 2011). Kajian pengaruh frekuensi pemakaian minyak goreng pada pengolahan bawang goreng Palu belum pernah dilakukan. Oleh karena itu perlu dilakukan penelitan yang bertujuan untuk mengetahui sifat fisik-kimia dan organanoleptik bawang goreng Palu yang digoreng pada berbagai taraf frekuensi pemakaian minyak goreng. Hasil kajian ini diharapkan dapat memberikan kontribusi untuk mengatasi permasalahan bawang goreng Palu.

\section{METODE PENELITIAN}

Bahan utama penelitian ini adalah umbi bawang merah lokal Palu yang diperoleh dari Desa Maku Kecamatan Dolo
Kabupaten Sigibiromaru Provinsi Sulawesi Tengah dan bahan pembantu berupa bahan kimia untuk keperluan analisis mutu kimia bawang goreng. Pelaksanaan penelitian diawali dengan pemilihan umbi bawang merah, pengupasan, pengirisan umbi ketebalan maksimum $1 \mathrm{~mm}$ dan pencampuran dengan tepung pelapis tapioka $1 \%(\mathrm{~b} / \mathrm{b})$. Irisan umbi bawang merah digoreng di atas wajan yang sumber panasnya berasal kompor gas elpiji. Jenis minyak yang digunakan adalah minyak goreng sawit merek Bimoli Spesial. Suhu penggorengan dipertahankan pada kisaran $160-180{ }^{\circ} \mathrm{C}$ hingga irisan umbi bawang yang digoreng menjadi matang. Setiap kali penggorengan rasio minyak:bawang goreng dipertahankan hingga tetap pada perbandingan 1:3 (b/v). Setelah matang bawang goreng direduksi kandungan minyaknya sesuai dengan cara yang diterapkan oleh mitra industri bawang goreng yakni menggunakan alat peniris minyak tipe SPIN-5 Agrowindo selama 5 menit.

Komponen mutu bawang goreng yang diamati meliputi (a) mutu fisik : rendemen bawang goreng, warna (Chromameter Minolta CR-200) dan tekstur (Lloyd's Universal Testing Instrument), (b) mutu kimia : kadar air dan kadar minyak (AOAC, 1984), asam lemak bebas (ALB) (Paquot, 1979), bilangan peroksida (Hills dan Thiel, 1949 yang dimodifikasi Adnan, 1980), bilangan thiobarbituric acid (TBA) (Ottolenghi, 1959 dalam Kikuzaki dan Nakatani, 1993) dan (c) mutu organoleptik dengan uji kesukaan panelis terhadap aroma, rasa, kerenyahan dan overall (Kartika dkk., 1992). Sebagai data penunjang dilakukan pula pengamatan derajat kejernihan minyak (Dimi dkk., 2012) dan komposisi asam lemak minyak goreng (Christophersou dan Glass, 1969 dalam Adnan, 1997).

Penelitian ini menggunakan rancangan acak lengkap (RAL) pola satu faktor. Sebagai perlakuan adalah berbagai taraf atau frekuensi pemakaian minyak goreng yaitu $\mathrm{F}_{0}$ : minyak segar, $\mathrm{F}_{1}: 1$ kali pemakaian, $\mathrm{F}_{2}: 2$ kali pemakaian, $\mathrm{F}_{3}: 3$ kali pemakaian, $\mathrm{F}_{4}: 4$ kali pemakaian, $\mathrm{F}_{5}: 5$ kali pemakaian dan $\mathrm{F}_{6}: 6$ kali pemakaian. Setiap taraf diulang tiga kali. Data yang diperoleh dianalisis secara statistik menggunakan uji F. Apabila memperlihatkan hasil berbeda nyata, dilanjutkan dengan uji BNJ (Gomez and Gomez, 1995). Untuk mengetahui derajat hubungan (r) antara variabel bebas dengan terikat digunakan analisis regresi Product Moment Pearson (Wijayanto, 2008). Taraf signifikansi r dilakukan dengan membandingkan $r_{\text {hitung }}$ dengan $r_{\text {tabel }}$ di mana kriteria pengujiannya terima $\mathrm{H}_{1}$ tolak $\mathrm{H}_{0}: \mathrm{r}_{\text {hitung }}>\mathrm{r}_{\text {tabel }}$ dan terima $\mathrm{H}_{0}$ tolak $\mathrm{H}_{1}: \mathrm{r}_{\text {hitung }} \leq \mathrm{r}_{\text {tabel }} . \mathrm{H}_{0}$ dan $\mathrm{H}_{1}=$ tidak dan terdapat hubungan atau pengaruh yang signifikan antara variabel bebas dengan terikat. 


\section{HASIL DAN PEMBAHASAN}

\section{Mutu Fisik Bawang Goreng}

Frekuensi pemakaian minyak goreng pengaruhnya tidak nyata terhadap rendemen, tetapi sangat nyata terhadap warna dan tekstur bawang goreng (Tabel 1).

Warna. Warna bahan pangan merupakan salah satu faktor penentu mutu. Sebelum faktor lain dipertimbangkan, warna terlebih dahulu tampil dan kadang-kadang sangat menentukan penerimaan konsumen. Warna dalam penelitian ini menunjukkan nilai terang (lightness) bawang goreng. Semakin tinggi nilai lightness (L*) menunjukkan bawang goreng tersebut semakin terang atau cerah. Pemakaian minyak goreng secara berulang-ulang akan menyebabkan penurunan nilai $L^{*}$ atau warna bawang goreng semakin gelap $(y=-1.008 x$ $\left.+60.23 ., \mathrm{r}=0.92^{* *}\right)$. Serupa yang dilaporkan oleh Kusucharid dkk. (2009) nilai L* menurun tetapi a* dan b* meningkat pada minyak yang sudah dipakai berulang menggoreng keripik ubi jalar. Hasil yang sama juga ditemukan pada lightness keripik kentang yang menurun setiap peningkatan frekuensi penggorengan (Hojjatoleslamy dan Sedaghat, 2012).

Penggorengan dapat digambarkan sebagai proses transfer panas dan massa air, yaitu panas dari minyak akan berpindah ke dalam bahan yang digoreng. Dengan adanya panas ini akan menyebabkan perpindahan massa air dari permukaan bahan ke lingkungannya dan dari bagian dalam bahan ke permukaan minyak. Di samping itu panas dari minyak goreng ini akan menyebabkan pula terjadinya serangkaian reaksi yang dapat memberikan pengaruh terhadap kenampakan bahan yang digoreng. Bawang merah lokal Palu mengandung protein $0,91-2,45 \%$ dan karbohidrat $8,40-11,75 \%$ (Alam dkk., 2012). Salah satu sifat kimia kedua senyawa ini adalah bereaksi membentuk senyawa berwarna coklat ketika ada pengaruh suhu pemanasan, disebut reaksi pencoklatan atau reaksi Maillard (Klopfer, 2011). Reaksi pencoklatan pada proses penggorengan juga dapat terjadi antara produk oksidasi minyak goreng dengan asam amino bawang merah. Menurut Hutapea dkk (2004) produk oksidasi asam lemak tidak jenuh seperti hidroperoksida, radikal alkoksi dan 2,4-alkadiena akan berkondensasi dengan gugus amina dari asam amino membentuk imina tidak jenuh yang berwarna coklat.

Reaksi pencoklatan merupakan urutan peristiwa yang dimulai dengan reaksi gugus amina pada asam amino, peptida atau protein dengan gugus hidroksil glikosidik pada gula, urutan diakhiri dengan pembentukan nitrogen berwarna coklat atau melanoidin. Reaksi ini telah memberikan perubahan besar pada industri makanan, sebab reaksi ini berpengaruh pada aroma, rasa dan warna (Yokotsuka, 1986). Warna coklat tersebut akan larut dalam minyak dan menyebabkan minyak menjadi berwarna coklat. Minyak yang berwarna coklat ini akan bermigrasi ke dalam rongga-rongga bahan yang digoreng. Penggunaan minyak goreng secara berulang-ulang akan menyebabkan peningkatan konsentrasi warna coklat dalam minyak sehingga bahan yang digoreng warnanya semakin coklat atau gelap. Hal ini ditunjukkan dengan adanya hubungan yang sangat nyata antara derajat kejernihan minyak dengan warna bawang goreng (Gambar 1). Serupa dengan kesimpulan hasil penelitian Rani dkk. (2010) ketika minyak goreng dipanaskan berulang-ulang, akan terjadi perubahan penampilan fisik minyak goreng seperti peningkatan viskositas, foaming, warna minyak semakin gelap, menurunkan titik asap serta dapat mengubah komposisi asam lemak dari minyak.

Tabel 1. Pengaruh frekuensi pemakaian minyak goreng terhadap rendemen, warna dan tekstur bawang goreng

\begin{tabular}{ccccc}
\hline $\begin{array}{c}\text { Frekuensi pemakaian } \\
\text { minyak goreng }\end{array}$ & $\begin{array}{c}\text { Rendemen } \\
(\%)\end{array}$ & $\begin{array}{c}\text { Warna } \\
\left(\mathrm{L}^{*}\right)\end{array}$ & $\begin{array}{c}\text { Derajat kejernihan minyak } \\
\text { goreng }(\% \mathrm{~T})\end{array}$ & $\begin{array}{c}\text { Tekstur } \\
(\mathrm{N} / \mathrm{mm})\end{array}$ \\
\hline F0 & $39,10 \pm 0,32$ & $59,77 \pm 0,44^{\mathrm{e}}$ & $55,99 \pm 1,89^{\mathrm{f}}$ & $6,52 \pm 1,03^{\mathrm{b}}$ \\
F1 & $38,32 \pm 0,51$ & $58,88 \pm 0,16^{\text {de }}$ & $55,89 \pm 1,48^{\text {ef }^{\mathrm{b}}}$ & $6,41 \pm 0,19^{\mathrm{b}}$ \\
F2 & $38,36 \pm 0,78$ & $58,58 \pm 0,39^{\mathrm{d}}$ & $51,77 \pm 1,28^{\mathrm{d}}$ & $3,83 \pm 0,09^{\mathrm{ab}}$ \\
F3 & $38,08 \pm 1,92$ & $58,33 \pm 0,18^{\mathrm{d}}$ & $49,65 \pm 2,36^{\text {cd }}$ & $6,30 \pm 1,08^{\mathrm{b}}$ \\
F4 & $37,45 \pm 0,52$ & $55,36 \pm 0,56^{\mathrm{b}}$ & $47,50 \pm 1,24^{\mathrm{bc}}$ & $5,22 \pm 1,81^{\mathrm{b}}$ \\
F5 & $36,83 \pm 0,66$ & $56,49 \pm 0,11^{\mathrm{c}}$ & $45,15 \pm 1,69^{\mathrm{ab}}$ & $4,08 \pm 2,11^{\mathrm{b}}$ \\
F6 & $36,82 \pm 0,41$ & $53,02 \pm 0,85^{\mathrm{a}}$ & $42,39 \pm 1,09^{\mathrm{a}}$ & $1,22 \pm 0,24^{\mathrm{a}}$ \\
\hline F. Hitung & $\mathrm{ns}$ & $* *$ & $* *$ & $* *$ \\
\hline BNJ 0,05 & - & 1,06 & 3,77 & 2,78 \\
\hline
\end{tabular}




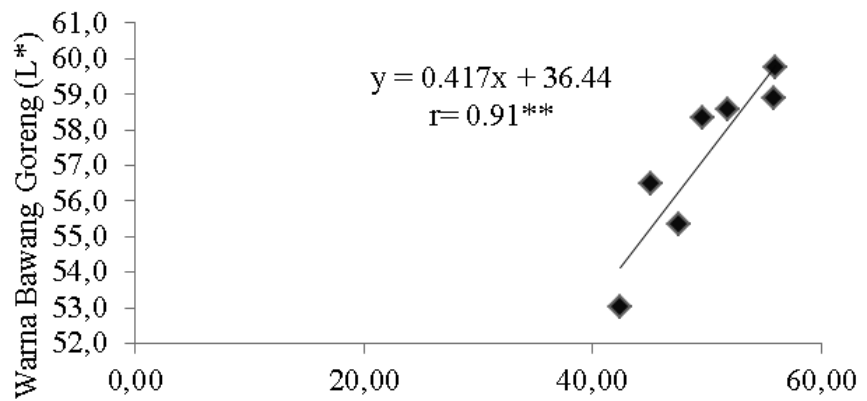

Derajat Kejernihan Minyak Goreng (\% T)

Gambar 1. Hubungan antara derajat kejernihan minyak dengan warna bawang goreng

Tekstur. Tekstur bawang goreng hasil penelitian ini menunjukkan pola menurun dengan bertambahnya frekuensi pemakaian minyak goreng $\left(\mathrm{y}=-0.684 \mathrm{x}+6.851\right.$., $\left.\mathrm{r}=0.77^{*}\right)$. Serupa yang dilaporkan oleh Hojjatoleslamy dan Sedaghat (2012) frekuensi pemakaian minyak goreng menyebabkan penurunan tekstur dan lightness keripik kentang serta meningkatkan indeks konsistensi minyak goreng dan bilangan peroksida. Hasil penelitian ini juga sesuai pernyataan Basuny dkk. (2009) bahwa penggunaan minyak bunga matahari pada proses penggorengan yang diulang selama lima kali berturutturut menyebabkan penurunan tekstur, rasa, penampakan dan warna keripik kentang varietas Osina, Glactica, dan Sponta. Sebaliknya titik asap, viskositas, bilangan asam, peroksida, TBA, kadar senyawa polar dan polimer, asam lemak yang teroksidasi serta kepekatan minyak goreng bunga matahari meningkat nyata setiap periode penggorengan. Serupa temuan Chen dkk. (2013) yang melaporkan bahwa kadar total senyawa polar minyak palm olein meningkat secara linear dengan meningkatnya waktu penggorengan. Menurut Dobarganes dan Marquez-Ruiz (2006) dalam Tabe (2008); Chen dkk. (2013) senyawa polar yang terbentuk ketika oksidasi minyak antara lain peroksida, asam, monoasilgliserol, diasilgliserol, alkohol, senyawa siklik, dimer dan polimer. Senyawa polar tersebut akan terserap ke dalam bawang yang digoreng, dimana gugus $\mathrm{OH}$ yang sifatnya higroskopis dapat memberikan kontribusi terhadap penurunan tekstur hasil gorengannya.

\section{Mutu Kimia Bawang Goreng}

Frekuensi pemakaian minyak goreng pengaruhnya sangat nyata terhadap kadar air, minyak, ALB, bilangan peroksida dan TBA (Tabel 2).

Kadar air. Kadar air bawang goreng secara berturutturut meningkat pada pelakuan $\mathrm{F}_{1}, \mathrm{~F}_{2}$ dan $\mathrm{F}_{3}(\mathrm{y}=-0.133 \mathrm{x} 2$ $+0.789 \mathrm{x}+2.658 ., \mathrm{r}=0.77 *)$. Peningkatan ini menandakan terjadinya migrasi air dari minyak goreng bekas penggorengan $\mathrm{F}_{0}$ ke dalam bahan yang digoreng. Pada titik tertentu yakni pada pemakaian minyak goreng keempat $\left(\mathrm{F}_{4}\right)$ kadar air bawang goreng mulai menguap yang disebabkan oleh semakin meningkatnya suhu penggorengan. Kondisi ini menyebabkan kadar air bawang goreng menurun. Serupa dengan temuan Onigbogi dkk. (2011) bahwa kadar air keripik ubi jalar menurun dengan bertambahnya frekuensi pemakaian minyak goreng biji melon dan kacang tanah.

Kadar minyak. Kadar minyak bawang goreng semakin berkurang dengan meningkatnya frekuensi pemakaian minyak goreng $\left(\mathrm{y}=-0.919 \mathrm{x}+42.92 ., \mathrm{r}=0.87^{* *}\right)$. Berbeda dengan temuan Onigbogi dkk. (2011) kadar minyak keripik ubi jalar meningkat dengan meningkatnya frekuesi pemakaian minyak goreng melon dan kacang tanah. Selama pemanasan minyak akan mengalami perubahan warna menjadi gelap, oksidasi, polimerisasi, hidrolisis dan peningkatan asam (Lawson,

Tabel 2. Pengaruh frekuensi pemakaian minyak goreng terhadap kadar air, minyak, ALB, bilangan peroksida dan TBA bawang goreng

\begin{tabular}{|c|c|c|c|c|c|}
\hline $\begin{array}{c}\text { Frekuensi pemakaian } \\
\text { minyak goreng }\end{array}$ & $\begin{array}{l}\text { Kadar } \\
\text { air }(\%)\end{array}$ & $\begin{array}{l}\text { Kadar } \\
\text { minyak } \\
(\%)\end{array}$ & $\begin{array}{c}\text { Kadar } \\
\text { ALB } \\
(\%)\end{array}$ & $\begin{array}{l}\text { Bilangan } \\
\text { peroksida } \\
(\mathrm{meq} / \mathrm{kg})\end{array}$ & $\begin{array}{c}\text { Bilangan TBA } \\
\text { (mg malonal } \\
\text { dehid } / \mathrm{kg} \text { ) }\end{array}$ \\
\hline F0 & $2,57 \pm 0,41^{\mathrm{a}}$ & $42,51 \pm 1,10^{c}$ & $0,39 \pm 0,00^{\mathrm{ab}}$ & $0,97 \pm 0,01^{b}$ & $0,36 \pm 0,02^{\mathrm{a}}$ \\
\hline $\mathrm{F} 1$ & $3,44 \pm 0,5^{\mathrm{ab}}$ & $42,30 \pm 1,06^{c}$ & $0,40 \pm 0,01^{\mathrm{ab}}$ & $0,97 \pm 0,01^{b}$ & $0,37 \pm 0,02^{\mathrm{ab}}$ \\
\hline $\mathrm{F} 2$ & $3,55 \pm 0,90^{\mathrm{ab}}$ & $41,96 \pm 0,68^{\mathrm{bc}}$ & $0,41 \pm 0,04^{\mathrm{b}}$ & $0,89 \pm 0,03^{\mathrm{a}}$ & $0,40 \pm 0,01^{\mathrm{b}}$ \\
\hline F3 & $4,40 \pm 0,42^{b}$ & $40,81 \pm 3,51^{\mathrm{abc}}$ & $0,37 \pm 0,01^{\mathrm{ab}}$ & $0,90 \pm 0,03^{\mathrm{a}}$ & $0,36 \pm 0,01^{\mathrm{a}}$ \\
\hline $\mathrm{F} 4$ & $2,93 \pm 0,17^{\mathrm{a}}$ & $36,92 \pm 1,83^{a}$ & $0,34 \pm 0,02^{\mathrm{a}}$ & $0,91 \pm 0,02^{\mathrm{a}}$ & $0,35 \pm 0,01^{\mathrm{a}}$ \\
\hline F5 & $3,53 \pm 0,37^{\mathrm{ab}}$ & $38,50 \pm 1,28^{\mathrm{abc}}$ & $0,34 \pm 0,04^{\mathrm{a}}$ & $0,94 \pm 0,03^{\mathrm{ab}}$ & $0,35 \pm 0,01^{\mathrm{a}}$ \\
\hline F6 & $2,59 \pm 0,10^{\mathrm{a}}$ & $38,14 \pm 1,21^{\mathrm{ab}}$ & $0,39 \pm 0,01^{\mathrm{ab}}$ & $0,89 \pm 0,02^{\mathrm{a}}$ & $0,39 \pm 0,01^{\mathrm{b}}$ \\
\hline F. Hitung & $* *$ & $* *$ & $* *$ & $* *$ & $* *$ \\
\hline BNJ 0,05 & 1,11 & 4,08 & 0,05 & 0,05 & 0,03 \\
\hline
\end{tabular}


1995; Choe dan Min, 2007). Reaksi oksidasi dan polimerisasi akan menyebabkan kekentalan minyak meningkat. Menurut Kalogianni dkk. (2011) viskositas dan reaksi polimerisasi pada minyak sawit dan zaitun meningkat setelah digunakan berulang kali untuk menggoreng keripik kentang.

Viskositas minyak juga dipengaruhi oleh komposisi asam lemak minyak goreng. Asam lemak jenuh memiliki viskositas lebih tinggi daripada asam lemak tidak jenuh dan semakin banyak ikatan ganda viskositas asam lemak semakin rendah (Sharoba dan Ramadan, 2012). Jumlah atom karbon asam lemak jenuh memiliki hubungan linear $(r=0,99)$ dengan viskositas minyak goreng (Geller dan Goodrum, 2000). Menurut Kita dkk. (2005) kadar minyak kentang goreng bertambah dengan meningkatnya kandungan asam lemak tidak jenuh dan menurun dengan meningkatnya kandungan asam lemak jenuh, asam lemak esensial dan asam lemak trans-isomer minyak goreng.

Oksidasi minyak goreng hasil penelitian ini ditandai dengan adanya penurunan kadar asam lemak tidak jenuh dan peningkatan asam lemak jenuh pada setiap waktu penggorengan (Gambar 5). Oleh karena itu penurunan kadar minyak bawang goreng tersebut di atas disebabkan oleh meningkatnya kandungan asam lemak jenuh dan viskositas minyak seiring dengan meningkatnya frekuensi penggorengan. Suatu jenis fluida yang mudah mengalir memiliki viskositas rendah, dan sebaliknya yang sulit mengalir memiliki viskositas tinggi. Oleh karena itu minyak yang kental (viskositas tinggi) memiliki laju alir lambat sehingga minyak yang dapat bermigrasi ke dalam bahan yang digoreng menurun.

Asam lemak bebas. Asam lemak bebas (ALB) termasuk salah satu komponen kimia bahan pangan terutama makanan gorengan yang sangat penting diperhatikan karena dapat berperan sebagai prekursor reaksi oksidasi. ALB terbentuk melalui reaksi hidrolisis terhadap trigliserida pada minyak goreng dan bahan yang digoreng. Bahan sebelum digoreng umumnya memiliki suhu kamar, kemudian akan kontak dengan minyak goreng yang bersuhu $130-200^{\circ} \mathrm{C}$ setelah berada di dalam panci penggorengan. Ketika mencapai suhu titik didihnya, air dalam bahan akan menguap dan uap yang dihasilkan bermigrasi ke dalam minyak panas. Dengan kondisi tersebut, sebagian trigliserida terhidrolisis menjadi asam lemak bebas dan gliserol ester parsial (diacylglycerols, monoacylglycerols dan bahkan gliserol) dalam waktu yang relatif singkat yakni 5 - 10 menit (Pokorny, 1998). ALB tersebut di atas akan bercampur dengan minyak goreng yang kemudian bermigrasi ke dalam bahan yang digoreng. Reaksi hidrolisis ini dipercepat oleh temperatur tinggi, tekanan udara dan jumlah air yang berlebihan (Lawson, 1995). Ketika dilakukan penggorengan pada bahan yang berkadar air tinggi akan memacu laju pembentukan asam lemak bebas. Hal ini teramati pada perlakuan $\mathrm{F}_{0}, \mathrm{~F}_{1}$ dan $\mathrm{F}_{2}$ hasil penelitian ini yang menunjukkan adanya peningkatan laju pembentukan ALB bersamaan dengan meningkatnya kadar air hasil gorengan bawang merah (Tabel 2).

ALB mudah mengalami oksidasi menghasilkan senyawa seperti hidroperoksida, aldehid, keton, hidrokarbon, furan dan asam (Gupta, 1992; Chen, 1996; Nawar, 1996; Choe dan Min, 2006) yang dapat diserap ke dalam makanan yang digoreng. Senyawa-senyawa ini dapat memacu reaksi oksidasi berantai sehingga akumulasi radikal bebas dalam makanan menjadi meningkat. Keberadaan senyawa tersebut juga dapat menimbulkan flavor dan aroma yang tidak dikehendaki. Oleh karena itu keberadaan ALB pada minyak atau makanan yang pengolahannya menggunakan minyak goreng harus dihindari atau ditekan seminimal mungkin.

Bilangan peroksida. Bilangan peroksida merupakan ukuran atau indikator asam lemak yang teroksidasi. Oleh karena itu gejala oksidasi asam lemak bebas teramati pada hasil analisis bilangan peroksida yang menunjukkan adanya peningkatan pada perlakuan $\mathrm{F}_{3}, \mathrm{~F}_{4}$ dan $\mathrm{F}_{5}$ (Gambar 2). Hal ini disebabkan oleh terbentuknya senyawa hidroperoksida akibat teroksidasinya asam lemak bebas yang sudah terbentuk pada perlakuan sebelumnya. Oksidasi ini ditandai dengan adanya penurunan kadar asam lemak bebas pada perlakuan $\mathrm{F}_{3}, \mathrm{~F}_{4}$ dan $\mathrm{F}_{5}$ (Gambar 2). Serupa dengan temuan Onigbogi dkk. (2011) bilangan peroksida keripik ubi jalar meningkat dengan meningkatnya frekuesi pemakaian minyak goreng melon dan kacang tanah. Demikian pula temuan Jaarin dan Kamisah (2012) yang melaporkan bahwa bilangan peroksida minyak sawit dan kedelai yang terekstrak dari keripik ubi jalar meningkat mulai dari penggorengan pertama hingga kelima.

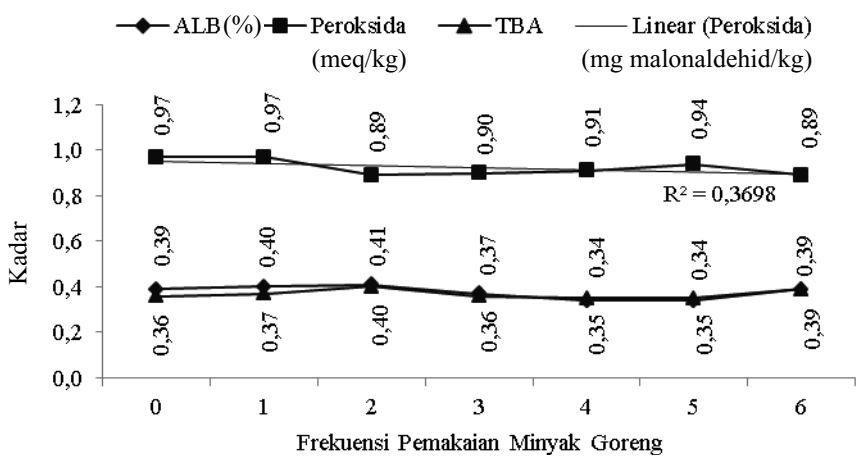

Gambar 2. Kadar asam lemak bebas, bilangan peroksida dan TBA pada berbagai frekuensi pemakaian minyak goreng

Bilangan TBA. Oksidasi lanjut terhadap hidroperoksida akan menghasilkan senyawa seperti propane, asam lemak bebas rantai pendek, keton, aldehid, lipoperoksida dan radikal bebas (Nawar, 1996; Kusucharid dkk., 2009; Leong dkk., 2009). Jika aldehid dalam hal ini malonaldehid direaksikan 
dengan asam thiobarbiturat akan memberikan warna merah (Rossel dan Pritcherd, 1983). Oleh karena itu gejala oksidasi asam lemak tidak jenuh dapat pula teramati pada hasil analisa bilangan TBA (thiobarbituric acid). Bilangan TBA dan asam lemak bebas meningkat pada perlakuan $\mathrm{F}_{2}$ dan $\mathrm{F}_{6}$, tetapi hal sebaliknya terjadi pada bilangan peroksida (Gambar 2). Peningkatan ini disebabkan terbentuknya malonaldehid akibat teroksidasinya senyawa hidroperoksida. Kondisi ini akan menyebabkan kadar hidroperoksida dalam minyak berkurang yang ditandai dengan adanya penurunan bilangan peroksida pada perlakuan $\mathrm{F}_{2}$ dan $\mathrm{F}_{6}$. Leong dkk. (2009) menyatakan bahwa bilangan peroksida menurun karena terjadinya dekomposisi senyawa hidroperoksida menghasilkan keton dan aldehid akibat penggunaan minyak dengan waktu yang lama. Disisi lain asam lemak bebas rantai pendek yang juga terbentuk ketika oksidasi hidroperoksida menyebabkan kadarnya dalam minyak meningkat. Hal ini teramati dengan meningkatnya kadar asam lemak bebas pada perlakuan $\mathrm{F}_{2}$ dan $\mathrm{F}_{6}$.

\section{Mutu Organoleptik Bawang Goreng}

Mutu organoleptik adalah komponen mutu pangan yang dapat dinilai berdasarkan kesukaan panelis dengan menggunakan pancaindra penglihat, penghidung (pencium), pengecap (perasa lidah), perasa tubuh dan pendengar. Mutu organoleptik bawang goreng dipengaruhi oleh bahan baku, bahan pembantu, cara pengolahan dan komponen fisik-kimia bawang goreng. Hasil penelitian frekuensi pemakaian minyak goreng sangat nyata mempengaruhi tingkat kesukaan panelis terhadap kerenyahan, tetapi tidak nyata terhadap aroma, rasa, dan overall bawang goreng (Tabel 3).
Hasil analisis tersebut di atas memberi petunjuk bahwa atribut organoleptik kerenyahan bawang goreng sangat diapresiasi oleh panelis. Beberapa hasil penelitian sebelumnya (Alam dkk., 2012; Ete dkk., 2009; Hutomo dkk., 2007) menyimpulkan bahwa atribut mutu organoleptik bawang goreng Palu yang paling disenangi oleh panelis adalah kerenyahan $>$ rasa $>$ aroma. Data yang tersaji pada Gambar 3 menunjukkan hubungan korelasi negatif antara frekuensi pemakaian minyak goreng dengan kerenyahan bawang goreng. Kerenyahan bawang goreng menurun dengan meningkatnya frekuensi pemakaian minyak goreng $(\mathrm{y}=-0.061 \mathrm{x}+4.008$, $\mathrm{r}=0.63$ ). Salah satu komponen umbi bawang merah yang memberikan kontribusi terhadap kerenyahan bawang goreng adalah karbohidrat. Menurut Pokorny (1998) polisakarida mempunyai peran lain pada produk hasil penggorengan. Selama proses penggorengan, polisakarida membentuk lapisan yang kompak di bagian permukaan bahan pada saat awal penggorengan. Pembentukan lapisan ini akan mencegah migrasi lemak ke dalam produk dan kehilangan kadar air dari bahan. Lapisan ini menghasilkan lapisan renyah yang disukai konsumen. Menurut Onigbogi dkk. (2011) frekuensi pemakaian dan jenis minyak goreng yang berbeda memberikan pengaruh sangat nyata terhadap sifat sensoris keripik ubi jalar. Nilai kerenyahan keripik ubi jalar yang digoreng dengan minyak biji melon segar 8,50, berkurang menjadi 7,8; 6,70 dan 5,10 pada penggorengan kedua, ketiga dan keempat. Tetapi hal sebaliknya meningkat pada keripik ubi jalar yang digoreng dengan minyak kacang.

Tabel 3. Pengaruh frekuensi pemakaian minyak goreng terhadap tingkat kesukaan panelis pada aroma, rasa, kerenyahan dan overall bawang goreng

\begin{tabular}{|c|c|c|c|c|}
\hline \multirow{2}{*}{$\begin{array}{c}\text { Frekuensi } \\
\text { penggorengan }\end{array}$} & \multicolumn{4}{|c|}{ Tingkat kesukaan panelis* } \\
\hline & Aroma & Rasa & Kerenyahan & Overall \\
\hline F0 & $3,23 \pm 0,43$ & $4,03 \pm 0,72$ & $4,20 \pm 0,66^{\mathrm{b}}$ & $3,73 \pm 0,83$ \\
\hline $\mathrm{F} 1$ & $3,37 \pm 0,56$ & $3,93 \pm 0,69$ & $3,90 \pm 0,71^{\mathrm{ab}}$ & $3,60 \pm 0,77$ \\
\hline $\mathrm{F} 2$ & $3,30 \pm 0,60$ & $3,70 \pm 0,75$ & $3,60 \pm 0,77^{\mathrm{a}}$ & $3,27 \pm 0,87$ \\
\hline F3 & $3,53 \pm 0,63$ & $4,03 \pm 0,67$ & $3,93 \pm 0,74^{\mathrm{ab}}$ & $3,53 \pm 0,90$ \\
\hline $\mathrm{F} 4$ & $3,47 \pm 0,57$ & $3,63 \pm 0,67$ & $3,77 \pm 0,63^{\mathrm{ab}}$ & $3,27 \pm 0,83$ \\
\hline F5 & $3,47 \pm 0,51$ & $3,70 \pm 0,60$ & $3,60 \pm 0,72^{\mathrm{a}}$ & $3,40 \pm 0,86$ \\
\hline F6 & $3,50 \pm 0,63$ & $3,83 \pm 0,68$ & $3,77 \pm 0,73^{\mathrm{ab}}$ & $3,40 \pm 0,82$ \\
\hline F. Hitung & tn & tn & $* *$ & tn \\
\hline BNJ 0,05 & - & - & 0,52 & - \\
\hline
\end{tabular}




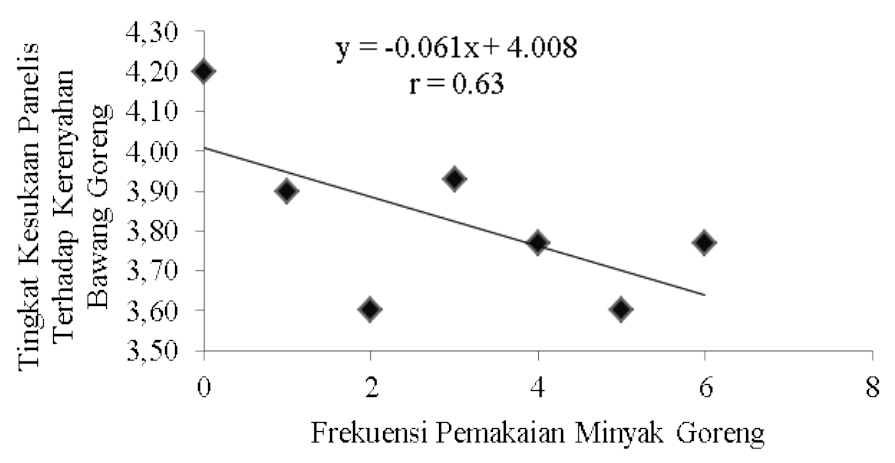

Gambar 3. Hubungan antara frekuensi pemakaaian minyak dengan kerenyahan bawang goreng

\section{Komposisi Asam Lemak Minyak Goreng}

Komposisi asam lemak minyak goreng juga dipengaruhi oleh frekuensi pemakaian minyak goreng. Kromatogram komposisi asam lemak minyak segar (0X) sebelum dan sesudah dipakai 1, 2, dan 3 kali menggoreng bawang goreng ditunjukkan pada Gambar 4. Data yang diolah dari hasil analisis komposisi asam lemak minyak goreng tersebut diketahui bahwa persentase peningkatan kadar asam lemak jenuh secara berturut-turut tertinggi pada $\mathrm{C}_{20}: 0(4,35 \%)$ $>\mathrm{C}_{16}: 0(3,42 \%)>\mathrm{C}_{14}: 0(2,86 \%)>\mathrm{C}_{18}: 0(0,48 \%)>\mathrm{C}_{12}: 0$ $(0,00 \%)$. Sebaliknya oksidasi asam lemak tidak jenuh paling tinggi ditemukan pada asam lemak C18 : $3(15,38 \%)>\mathrm{C} 18$ : $2(4,83 \%)>\mathrm{C} 18: 1(1,48 \%)>\mathrm{C} 16: 1(0,0 \%)$.

Persentase asam lemak yang teroksidasi tersebut di atas mengandung maksud bahwa semakin besar jumlah ikatan rangkap semakin mudah asam lemak tersebut teroksidasi. Kecepatan oksidasi terhadap asam lemak berkaitan dengan jumlah ikatan rangkap dalam rantai karbon molekul (Yoshida dkk., 1990). Asam lemak yang berikatan rangkap tiga relatif lebih cepat teroksidasi dibandingkan dengan yang berikatan rangkap dua dan satu. Linoleat dioksidasi 10 kali lebih cepat daripada oleat, dan linolenat dioksidasi 20 - 30 kali lebih cepat daripada oleat (Chen, 1996).

Data yang tersaji pada Gambar 5 menunjukkan adanya kecenderungan peningkatan kadar asam lemak jenuh (reaksi polimerisasi) dan penurunan asam lemak tidak jenuh (oksidasi) sejalan dengan meningkatnya frekuensi pemakaian minyak goreng. Persentase asam lemak yang terpolimerisasi dan teroksidasi paling tinggi ditemukan pada penggorengan menggunakan minyak 3 kali pemakaian jika dibandingkan asam lemak dari minyak segar. Serupa dengan hasil penelitian sebelumnya bahwa pemakaian minyak sawit pada penggorengan kelima irisan ubi jalar menyebabkan penurunan asam lemak tak jenuh ganda $2,57 \%$ dan tak jenuh tunggal 1,49\% serta peningkatan asam lemak jenuh $0,89 \%$ dari komposisi asam lemak minyak segarnya (Jaarin dan Kamisah,
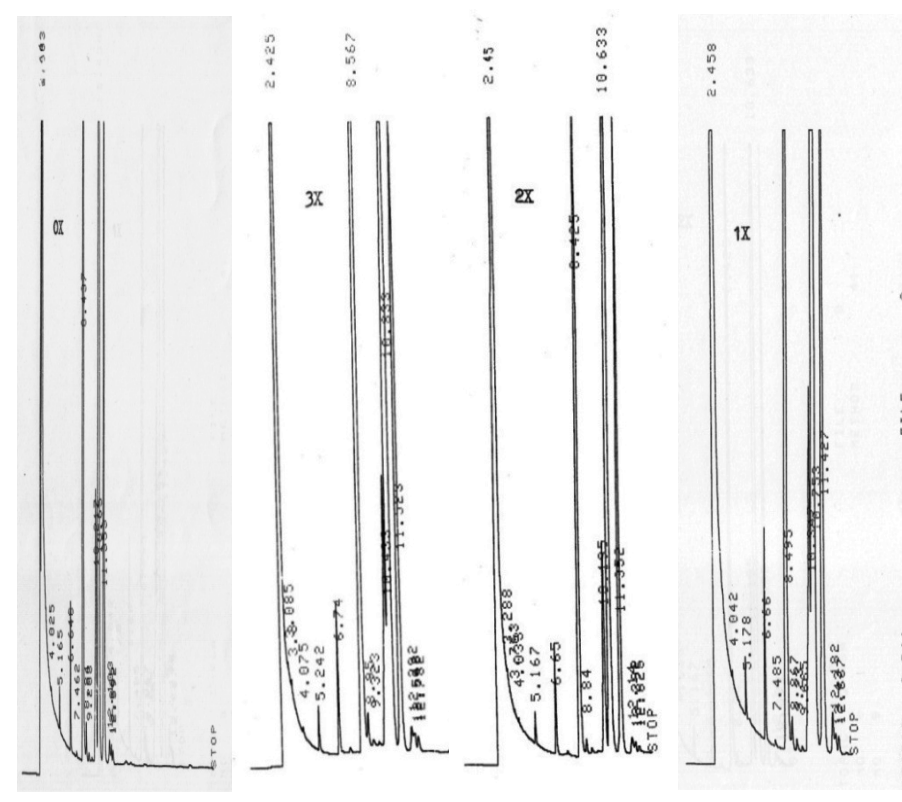

Gambar 4. Kromatogram asam lemak minyak sebelum dan sesudah digunakan menggoreng

2012). Perubahan komposisi asam lemak jenuh dan tidak jenuh pada minyak goreng yang telah dipakai berulang untuk menggoreng juga telah dilaporkan oleh peneliti sebelumnya (Andrikopoulos dkk., 2002; Alireza dkk., 2010; Chacko dan Rajamohan, 2011; Abdulkarim dan Ghazali, 2012; Kamisah dkk., 2012).

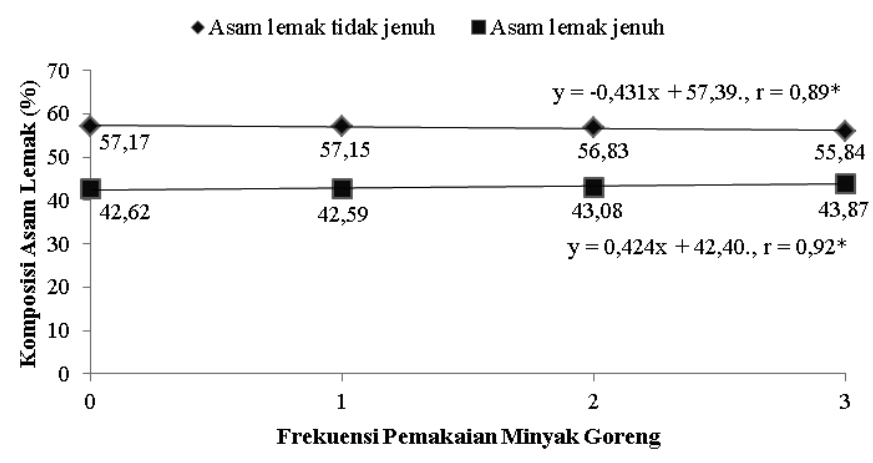

Gambar 5. Hubungan antara frekuensi pemakaian minyak dengan komposisi asam lemak

\section{KESIMPULAN}

Frekuensi pemakaian minyak goreng pengaruhnya sangat nyata menurunkan warna, tekstur, kadar air, minyak dan tingkat kesukaan panelis terhadap kerenyahan bawang goreng Palu serta meningkatkan laju oksidasi asam lemak tidak jenuh pada minyak goreng. Mutu fisik-kimia dan organoleptik bawang goreng Palu secara berturut-turut terbaik diperoleh dari penggorengan menggunakan minyak goreng 
segar, 1, 2 dan 3 kali pemakaian. Pemakaian minyak goreng $>3$ kali asam lemak bebas telah teroksidasi sehingga kurang layak untuk digunakan jika ditinjau dari aspek daya tahan simpan bawang goreng dan kesehatan.

\section{DAFTAR PUSKATA}

Abdulkarim, S.M. dan Ghazali, H.M. (2012). Fatty acid ratios and their relative amounts as indicators of oil stability and extent of oil deterioration during frying. Journal of Food Agriculture and Environment 10(2): 33-38.

Adams, J.B. (2004). Raw materials quality and the texture of processed vegetables. Woodhead Publishing Ltd and CRC Press LLC.

Adnan, M. (1980). Lipid Properties and Stability of Partially Defatted Peanuts. Ph D. Tesis. University of Illinois, Urbana, Champaign.

Adnan, M. (1997). Teknik Kromatografi untuk Analisa Bahan Makanan. Andi, Yogyakarta.

Alam, N., Rostiati dan Muhardi (2012). Optimalisasi Peningkatan Mutu dan Daya Saing Produk Unggulan Bawang Merah Lokal Palu. Laporan Hasil Penelitian Strategis Nasional Tahun I, Lembaga Penelitian Universitas Tadulako, Palu.

Alam, N., Rostiati dan Muhardi (2013). Optimalisasi Peningkatan Mutu dan Daya Saing Produk Unggulan Bawang Merah Lokal Palu. Laporan Hasil Penelitian Strategis Nasional Tahun II, Lembaga Penelitian Universitas Tadulako, Palu.

Albert, S. dan Mittal, G.S. (2002). Comparative evaluation of edible coatings to reduce fat uptake in a deep-fried cereal product. Food Research International 35: 445458.

Alireza, S., Tan, C.P., Hamed, M. dan Che Man, Y.B. (2010). Effect of frying process on fatty acid composition and iodine value of selected vegetable oils and their blend. International Food Research Journal 17: 295-302

Andrikopoulos, N.K., Kalogeropoulos, N., Falirea, A. dan Barbagianni, M.N. (2002). Performance of virgin olive oil and vegetable shortening during domestic deepfrying and pan-frying of potatoes. International Journal of Food Science and Technology 37: 177-190.

AOAC. (1984). Official Methodes of Analysis of the Association of Analytical Chemist. $14^{\text {th }}$ ed. AOAC Inc. Arlington. Virginia.
Basuny, A.M.M., Mostafa, D.M.M dan Shaker, A.M. (2009). Relationship between chemical composition and sensory evaluation of potato chips made from six potato varieties with emphasis on the quality of fried sunflower oil. World Journal of Dairy and Food Sciences 4(2): 193-200.

Chacko, C. dan Rajamohan, T. (2011). Repeatedly heated cooking oils alter platelet functions in cholesterol fed Sprague dawley rats. International Journal of Biological and Medical Research 2(4): 991-997.

Chen, Q. (1996). Flavor compound in fats and oil. Dalam: Hui, Y.H. (Ed.). Bailey's Industrial Oil and Fat Product. Fifth Edition, Edible Oil and Fat Products General Application, Vol. I hal 83-104. John Wiley and Sons, Inc, New York.

Chen, W., Chiu, C.P., Cheng, W., Hsu, C. dan Kuo, M. (2013). Total polar compounds and acid values of repeatedly used frying oils measured by standard and rapid methods. Journal of Food and Drug Analysis 21(1): 5865.

Choe, E. dan Min, D.B. (2006). Chemistry and reactions of reactive oxygen species in foods. Critical Reviews in Food Science and Nutrition 46(1): 1-22.

Choe, E. dan Min, D.B. (2007). Chemistry of deep-fat frying oils. Journal of Food Science 72(5): R77-R86.

Dimi , E., Premovi . T. dan Taka i, A. (2012). Effects of the contents of impurities and seed hulls on the quality of cold-pressed sunflower oil. Czech Journal of Food Sciences 30(4): 343-350.

Ete, A. dan Alam, N. (2009). Karakteristik mutu bawang goreng palu sebelum peyimpanan. Jurnal Ilmu-Ilmu Pertanian Agroland 16(4): 273-280.

Ete, A., Alam, N. dan Rahim, A. (2009). Profil Mutu Bawang Goreng Palu. Laporan Hasil Penelitian Hibah Kompetitif Penelitian Sesuai Prioritas Nasional Batch III. Fakultas Pertanian. Universitas Tadulako, Palu.

Geller, D.P. dan Goodrum, J.W. (2000). Rheology of vegetable oil analogs and triglycerides. Journal of the American Oil Chemists'Society 77(2): 111-114.

Gomez, K.A. dan Gomez, A.A. (1995). Statistical Procedures for Agricultural Research. John Wiley and Sons, Inc, Filiphine.

Gupta, M.K. (1992). Designing frying fat. Dalam: Ed. Thomas H. Applewhite. Proceedings of the World Conference on Oilseed Technology and Utilization, AOCS Champaign, Illinois. 
Hojjatoleslamy, M. dan Sedaghat, L. (2012). The effect of frying on the chemical and rheological properties of frying oil and physical properties of produced potato chips. Annual Transactions of The Nordic Rheology Society 20: 319-324.

Hutapea, E.B., Parkányiová, L., Parkányiová, J., Miyahara, M., Sakurai, H., dan Pokorný, J. (2004). Browning reactions between oxidised vegetable oils and amino acids. Czech Journal of Food Sciences 22(3): 99-107.

Hutomo, G.S., Alam, N. dan Sahyuni (2007). Mutu Bawang Goreng (Allium ascalonicum L.) pada Berbagai Produk Industri Rumah Tangga. Laporan Hasil Penelitian Mandiri, Fakultas Pertanian. Universitas Tadulako, Palu.

Jaarin, K. dan Kamisah, Y. (2012). Repeatedly heated vegetable oils and lipid peroxidation. http://www.intechopen.com/ books/lipid-peroxidation/repeatedly-heated-vegetableoils-and-lipid-peroxidation. [27 Januari 2014].

Kalogianni, E.P., Karapantsios, T.D. dan Miller, R. (2011). Effect of repeated frying on the viscosity, density and dynamic interfacial tension of palm and olive oil. Journal of Food Engineering 105: 169-179.

Kamisah, Y., Shamil, S., Nabillah, M.J., Kong, S.Y., Hamizah, N.A.S., Qodriyah, H.M.S., Azlina, M.F.N., Azman, A. dan Jaarin, K. (2012). Deep-fried keropok lekors increase oxidative instability in cooking oils. Malaysian Journal of Medical Sciences 19(4): 58-63.

Kartika, B., Hastuti, P. dan Supartono, W. (1992). Pedoman Uji Indrawi Bahan Pangan. Pusat Antar Universitas Pangan dan Gizi. Universitas Gadjah Mada, Yogyakarta.

Kikuzaki, H. dan Nakatani, N. (1993). Antioxidant effects of some ginger constituents. Journal of Food Science 58: 1407-1410.

Kita, A., Lisin'ska, G. dan Powolny, M. (2005). The influence of frying medium degradation on fat uptake and texture of french fries. Journal of the Science of Food and Agriculture 85: 1113-1118.

Klopfer, M. (2011). Frying, boiling and the Maillard reaction http://ediblesciencefaire.wordpress.com/2011/06/01/ maillard-reaction/. [01 Februari 2014).

Kusucharid, C., Jangchud, A. dan Thamakor, P. (2009). Changes in characteristics of palm oil during vacuum and atmospheric frying conditions of sweet potato. Kasetsart Journal (Natural Science) 43: 298-304.

Lawson, H.(1995). Food Oils and Fats: Technology, Utilization and Nutrition. Chapman and Hall, New York.
Leong, X., Najib, M.N.M., Das, S., Mustafa, M.R. dan Jaarin, K. (2009). Intake of repeatedly heated palm oil causes elevation in blood pressure with impaired vasorelaxation in rats. The Tohoku Journal of Experimental Medicine 219: $71-78$.

Nawar, W.W. (1996). Lipids. Dalam: O.R. Fennema (Ed.). Food Chemistry. Third Edition, hal 225-319. Marcel Dekker, Inc, New York.

Nazrun, A., Chew, C.M., Norazlina, M., Kamsiah, J. dan Ima, N. (2007). The effects of repeatedly heated frying oil and high cholesterol diet on the bone in ovariectomised rats. Malaysian Journal of Nutrition 13(1): 89-99.

Onigbogi, I.O., Olatunji, T.O., Nupo, S.S. dan Bello, T.K. (2011). Effect of repeated frying operations on the quality attributes of frying oil and aceptability of sweet potato chips. Journal of Sciences and Multidisciplinary Research 3: 10-15.

Paquot, C. (1979). Standard Method for the Analysis of Oil, Fat and Derivates. $6^{\text {th }}$ Ed. Pergamon Press, Oxford.

Pokorny, J. (1998). Substrate influence on the frying process. Grasas y Aceites 49(Fasc. 3-4): 265-270.

Rani, A.K.S., Reddy, S.Y., dan Chetana, R. (2010). Quality changes in trans and trans free fats/oils and products during frying. European Food Research and Technology 230(6): 803-811.

Rossel dan Pritcherd, J.L. (1983). Analysis of Commercial Oil Sources. Elseveir Applied Science, London.

Sharoba, A.M. dan Ramadan, M.F. (2012). Impact of frying on fatty acid profile and rheological behaviour of some vegetable oils. Journal of Food Processing and Technology 3(7): 1-9.

Shieh, C-J., Chang, C-Y. dan Chen, C-S. (2004). Improving The Texture of Fried Food. Woodhead Publishing Ltd and CRC Press LLC.

Tabee, E. (2008). Lipid and Phytosterol Oxidation in Vegetable Oils and Fried Potato Products. Doctoral Thesis. Swedish University of Agricultural Sciences. Uppsala. pp.21.

Wijayanto, A. (2008). Analisis Korelasi product Moment Pearson. http://eprints.undip.ac.id/6608/1/Korelasi Product Moment.pdf. [14 September 2012].

Yokotsuka, T. (1986). Soy sauce biochemistry. Advances in Food Research 30: 195-329.

Yoshida, H., Hirooka, N. dan Kajimoto, G. (1990). Microwave energy effects on quality of some seed oils. Journal of Food Science 55: 1412-1416. 